\title{
Effects of Sewage Sludge at different pH Levels on Ipomoea Aquatica
}

\author{
A. Nessa ${ }^{a}$, Shafiqur Rahman ${ }^{a}$, M. T. A. Chowdhury ${ }^{b}$ and Z. Parveen ${ }^{a}$ * \\ ${ }^{a}$ Department of Soil, Water and Environment, University of Dhaka, Dhaka-1000, Bangladesh. ${ }^{b}$ Bangladesh- \\ Australia Centre for Environmental Research (BACER-DU), Department of Soil, Water and Environment, \\ University of Dhaka, Dhaka-1000, Bangladesh.
}

\begin{abstract}
An experiment was conducted to study the effects of sewage sludge on the response of Ipomoea aquatica to plant nutrients and heavy metals in soil at different soil $\mathrm{pH}$. An incubation study was done for the selection of four individual pH levels, viz., 4.7, 5.7, 6.6 and 7.8 to be used for the plant culture experiment. Yield of Ipomoea aquatica and concentration and uptake of $\mathrm{N}, \mathrm{P}, \mathrm{K}, \mathrm{Ca}, \mathrm{Mg}, \mathrm{Cd}, \mathrm{Cu}, \mathrm{Fe}, \mathrm{Mn}$ and $\mathrm{Zn}$ in the plant were evaluated. Application of sewage sludge in soil increased the concentration and uptake of the elements in Ipomoea. Slightly acidic to slightly alkaline $\mathrm{pH}$ was found to be better for amendment of soil with sewage sludge.
\end{abstract}

Key words : Sewage sludge, $\mathrm{pH}$, Ipomoea aquatica, Accumulation, Uptake.

\section{Introduction}

Bangladesh is an agrarian country and agriculture is the backbone of our national economy. The soils of Bangladesh are generally poor in quality so far the fertility status is concerned. To increase soil fertility, commercial fertilizers have been used in agriculture for a long period. Sewage sludges are also used in agriculture because they act as a fertilizer. Agricultural use of sewage sludge has been increasingly favored as a means of disposal and beneficial use (Sikder $e t$ al. 2007). Land application of sewage sludge can both have beneficial and harmful effects. Growing crops may use its nutrients such as $\mathrm{N}, \mathrm{P}, \mathrm{K}, \mathrm{Ca}, \mathrm{Mg}$ etc., micronutrients and organic matter. It also improves the physical, chemical and biological conditions of soil with no danger, in short or medium term, to the environment as well as to the crops (White et al. 1997; Aggelides and Londra 2000; Benitez et al. 2001; Selivanovskaya et al. 2001; Sikder et al. 2007). However, the presence of heavy metals and organic pollutants in sewage sludge can result in phytotoxic effects, soil and water contamination and accumulation of heavy metals in food supplies (Keller et al. 2002; Yingming and Corey 1993).

To minimize the threat of food-chain contamination, accurate estimation of movement and potential for plant accumulation and food-chain cycling of sludge-borne heavy metals is important (Yingming and Corey 1993). Either the metal contents in the sludge or the application should be reduced below quantities accepted by given prescriptions.
Liming is a common practice in agriculture to raise soil $\mathrm{pH}$ of acid soil and also to reduce the solubility of heavy metals. The application of lime should generally be considered for strongly and moderately acid soils to improve the physical, chemical and biological properties of the soils, although many factors, such as kind of crops, soil type and climate influence plant response to lime. Application of lime in low $\mathrm{pH}$ soils neutralizes soil acidity, reduces toxicity levels of Al, $\mathrm{Fe}$ and $\mathrm{Mn}$ and improves soil properties. There are reports on the effects of lime addition to reduce heavy metal solubility (Basta and Sloan 1999; Fang and Wong 1999; Krebs et al. 1998; Little et al. 1991). Peles et al. (1998) found that Zn, $\mathrm{Cu}, \mathrm{Cd}$ and $\mathrm{Pb}$ concentrations in various plant species were significantly lower in plants collected from limed compared to unlimed sludge treated soils though these effects were different for the individual metals.

Ipomoea aquatica, a leafy vegetable commonly known as Kalmi shak, is widely cultivated in Bangladesh and meets the nourishment here, especially in the rural area. Kalmi is a good source of vitamin A and C as well as iron and calcium, although it is a hyper accumulator of toxic heavy metals. The variability of $\mathrm{pH}$ has significant effect on agricultural production. The availability of micronutrients is related to soil $\mathrm{pH}$. It is well known that as $\mathrm{pH}$ decreases, the ability of soils to adsorb and hold metals decreases (Brady and Weil 2002). 
The present study aims to assess the role of sewage sludge as a source of plant nutrients at different $\mathrm{pH}$ levels on the growth and nutritional status of Ipomoea aquatica and its response to heavy metals.

\section{Materials and Methods}

\section{Soil sample collection and sample preparation}

The soil used in the present study was acidic in nature and it belonged to the Ramnagar soil series. The soil samples were collected from Malackochha of Sherpur district, Bangladesh. The collected soil samples were dried in air for 3 days (at $\sim 35^{\circ} \mathrm{C}$ ) by spreading in a thin layer on a clean piece of paper after it was transported to the laboratory. Visible roots and debris were removed from the soil and discarded. For hastening the drying process, the soil samples were exposed to sunlight. After air-drying, a portion of larger and massive aggregates were broken down by gently crushing them using a wooden hammer. Ground samples were screened to pass through a $2 \mathrm{~mm}$ stainless still sieve. The sieved samples were then mixed thoroughly for making the composite sample. Soil samples were preserved in plastic bags and labelled properly marking the soil name, sample number, date of collection, etc. These soil samples were used for various physical, chemical and physico-chemical analyses. The bulk of the soil samples collected for the pot experiment was crushed to make the bigger clods smaller and then was screened through a $5 \mathrm{~mm}$ sieve.

\section{Collection and processing of sewage sludge samples}

The treated sewage sludge samples were collected from Pagla Sewage Treatment Plant, Dhaka, Bangladesh. The sewage sludge samples were transported into the laboratory and were dried in the sun for 3 days (at $\sim 35^{\circ} \mathrm{C}$ ). The samples were then processed and prepared for chemical analyses and application into soil.

\section{The Experiments}

In order to study the effects of liming on changing soil $\mathrm{pH}$ as well as the effects of sewage sludge on plants at different $\mathrm{pH}$ levels, the experiment was divided into two parts viz., (i) a laboratory incubation study and (ii) a pot culture experiment with plants.

\section{Laboratory Incubation Study}

An incubation study was carried out at room temperature in the laboratory of the Department of Soil, Water and
Environment, University of Dhaka. In the incubation study, $20 \mathrm{gm}$ of soil samples into $50 \mathrm{ml}$ size beakers were used. The soil samples were limed with 13 different amounts of $\mathrm{Ca}(\mathrm{OH})_{2}(0.0,0.01,0.02,0.04,0.06,0.08,0.10,0.12,0.16$, $0.20,0.24,0.28,0.30 \mathrm{mg} / \mathrm{pot})$ to raise the soil $\mathrm{pH}$. These amounts corresponds to $0.0,1.1,2.2,4.4,6.6,8.8,11.0,13.2$, 17.6, 22.0, 26.4, 28.0 and $33.0 \mathrm{t} \mathrm{Ca}(\mathrm{OH})_{2} \mathrm{ha}^{-1}$ soil, respectively. The soil and $\mathrm{Ca}(\mathrm{OH})_{2}$ were mixed thoroughly and were moistened with distilled water. The beakers were then covered with aluminum foil and allowed to incubate to observe the changes in $\mathrm{pH}$ of the soils. Distilled water was added to the soils every week to recover the loss of water from the soil. Thus, the soils were kept moist throughout the incubation period. The study was continued for a total period of 28 days with 4 individual incubation periods, viz., 7, 14, 21 and 28 days. Each treatment was replicated thrice for every incubation day.

The $\mathrm{pH}$ of the set of soils (with 13 rates of $\mathrm{Ca}(\mathrm{OH})_{2}$ ) under each incubation period was measured using a glass electrode $\mathrm{pH}$ meter (Imamul Huq and Alam 2005). From the $\mathrm{pH}$ of all the soils under the incubation study (Table III), four (4) $\mathrm{pH}$ levels: $4.7,5.7,6.6$ and 7.8 were selected for the pot culture experiment.

\section{The pot culture experiment}

In order to study the effects of sewage sludge on plants at different soil $\mathrm{pH}$ levels, a pot culture experiment with an upland crop, Ipomoea aquatica, was done. The experiment was carried out using the collected acidic soil amended with sewage sludge@ $5 \mathrm{tha}^{-1}$ soil and without amending the soil with sewage sludge. The non-amended soils and the soils amended with sewage sludge are symbolized as $S_{0}$ and $S_{1}$, respectively, in the text. Four different $\mathrm{pH}$ levels viz., 4.7, 5.7, 6.6 and 7.8, as selected from the incubation study, were used for the pot experiment and are designated as $\mathrm{pH}_{0}, \mathrm{pH}_{1}$, $\mathrm{pH}_{2}$ and $\mathrm{pH}_{3}$, respectively, in the text. To make the $\mathrm{pH}$ of the soils $(1.5 \mathrm{~kg}) \mathrm{kept}$ in the pots for plant culture at the selected $\mathrm{pH}$ levels of 4.7, 5.7, 6.6 and 7.8, $\mathrm{Ca}(\mathrm{OH})_{2}$ amounting 0 , $0.75,1.5$ and $3.0 \mathrm{gm}$ were added, respectively. These amounts of $\mathrm{Ca}(\mathrm{OH})_{2}$ correspond to $0,1.1,2.2$ and $4.4 \mathrm{t} \mathrm{ha}^{-1}$, respectively. The different treatment levels, with their codes, used in this experiment are presented in the Table I. All the experiments were done in triplicates. Accordingly, a total of 24 pots $\left[2\right.$ rates $\left(0\right.$ and $\left.5 \mathrm{tha}^{-1}\right)$ of sewage sludge $\times 4 \mathrm{pH}$ levels $\times 1$ crop $\times 3$ replications $=24$ pots $]$ were used in this pot experiment; 12 pots were used for the non-amended soils and 12 pots for the sewage sludge amended soils. 
Table I: Different treatment levels, with their codes, used in the experiment.

\begin{tabular}{c|c|c}
\hline \multicolumn{2}{c|}{ Treatment } & \multirow{2}{*}{ Code } \\
\hline Sewage sludge & $\mathrm{pH}$ levels & \\
\hline \multirow{3}{*}{$\mathrm{S}_{0}$} & 4.7 & $\mathrm{~S}_{0} \mathrm{pH}_{0}$ \\
& 5.7 & $\mathrm{~S}_{0} \mathrm{pH}_{1}$ \\
& 6.6 & $\mathrm{~S}_{0} \mathrm{pH}_{2}$ \\
& 7.8 & $\mathrm{~S}_{0} \mathrm{pH}_{3}$ \\
$\mathrm{~S}_{1}$ & 4.7 & $\mathrm{~S}_{1} \mathrm{pH}_{0}$ \\
& 5.7 & $\mathrm{~S}_{1} \mathrm{pH}_{1}$ \\
& 6.6 & $\mathrm{~S}_{1} \mathrm{pH}_{2}$ \\
& 7.8 & $\mathrm{~S}_{1} \mathrm{pH}_{3}$ \\
\hline
\end{tabular}

\section{Pot preparation}

Two kg sized earthen pots with no hole at the bottom were used. Air-dried $5 \mathrm{~mm}$ sieved soil samples amounting $1.5 \mathrm{~kg}$ were taken in each of the earthen pots. The soils were limed with $\mathrm{Ca}(\mathrm{OH})_{2}$ as per the calculated amounts to raise the $\mathrm{pH}$ of the soils to the four selected levels. After addition of the liming material into the soil, the pots were kept for two weeks with occasional mixing and watering of the soil. After two weeks, sewage sludge @ $5 \mathrm{t} \mathrm{ha}^{-1}$ was added only to the set of twelve pot-soils and mixed thoroughly and then kept for three days to decompose the sludge.

\section{Sowing of seeds}

Certified seeds of Ipomoea aquatica were collected from Bangladesh Agricultural Research Institute (BARI). Ten seeds of Ipomoea aquatica were sown on March 15, 2008 in each of the pots and allowed to germinate. After germination, five seedlings were kept in each pot and allowed to grow. All the pots were arranged in the net-house in a completely randomized design.

\section{Plant culture}

Plants received watering everyday. Watering of the pots was made twice daily at the morning and in the afternoon depending on the weather condition. Sometimes watering was done in a gap when the soil was saturated with rainwater. Tap water was used for this purpose. Intercultural operations were carried out whenever necessary. Weeds were removed manually. Positions of the pots were changed every alternate day to allow equal exposure of each of the pots to sunlight. Adequate plant protection measures were taken during the growing period. During the cultivation, different parameters like growth, appearance of any symptoms etc. were noted.

\section{Collection and processing of plant samples}

Plants were allowed to grow for 42 days after emergence of the seedlings and then sampling of the plants was done. At harvest, the plants from every pot were collected individually. The plants were harvested manually by uprooting them carefully from the pots. The roots of the harvested plants were washed first with tap water and then again with de-ionized distilled water three times to remove ions from the root free space as well as to dislodge any adhering particles on the root surface. Aerial parts of the plants were also washed. The wet samples were dried using paper towels. The plant samples were separated into two parts - root and edible parts (shoot and leaf). The samples were first air-dried and then oven-dried at $70^{\circ} \pm 5^{\circ} \mathrm{C}$ for 48 hours and the dry weight of the plant samples were taken. The dried plant samples were then ground to pass a $0.2 \mathrm{~mm}$ sieve. The ground plant samples were mixed thoroughly to make it composite and stored in a dry place for further chemical analyses.

\section{Laboratory analysis}

Various physical, chemical and physico-chemical properties of the soil and sewage sludge samples were analysed in the laboratory, following the procedures described in Imamul Huq and Alam (2005). The background concentrations of total Calcium (Ca), Cadmium (Cd), Copper $(\mathrm{Cu})$, Lead $(\mathrm{Pb})$, Magnesium (Mg), Manganese $(\mathrm{Mn})$, Nitrogen $(\mathrm{N})$, Phosphorus (P), Potassium (K) and Zinc ( $\mathrm{Zn})$ in the soils (pre- and post-experiment), plants and sewage sludge were determined.

\section{Results and Discussion}

\section{Soil and sewage sludge properties}

The selected soil and sewage sludge samples were analyzed to ascertain the levels of nutrients as well as other elements present (Table II).

\section{Incubation study: Changes in soil pH due to liming}

The initial $\mathrm{pH}$ of the collected soil was 4.7 and the $\mathrm{pH}$ levels have been found to increase up to a maximum of 11.62 after the incubation period of 28 days due to the application of different amounts of $\mathrm{Ca}(\mathrm{OH})_{2}$ (Table III). Among these $\mathrm{pH}$ values four $\mathrm{pH}$ levels of 4.7, 5.7, 6.6 and 7.8 have been selected for the pot culture experiment. 
Table II: Physical, chemical and physico-chemical properties of the soil and the sewage sludge.

\begin{tabular}{|c|c|c|}
\hline Soil properties & Soil & Sewage sludge \\
\hline $\mathrm{pH}$ & 4.7 & 3.3 \\
\hline Moisture Content (\%) & 4.0 & 62 \\
\hline Textural class & Loam & - \\
\hline Organic matter $(\%)$ & 1.10 & 7.10 \\
\hline Available $\mathrm{N}\left(\mathrm{mg} \mathrm{kg}^{-1}\right)$ & 355.20 & 390 \\
\hline Available $\mathrm{P}\left(\mathrm{mg} \mathrm{kg}^{-1}\right)$ & 6.10 & 312 \\
\hline Available $\mathrm{K}\left(\mathrm{mg} \mathrm{kg}^{-1}\right)$ & 33.20 & 84.33 \\
\hline Total N (\%) & 0.14 & 0.62 \\
\hline Total P (\%) & 0.03 & 0.43 \\
\hline Total K (\%) & 0.08 & 0.28 \\
\hline Total Fe (\%) & 0.28 & 0.77 \\
\hline Total $\mathrm{Ca}\left(\mathrm{mg} \mathrm{kg}^{-1}\right)$ & 30 & 560 \\
\hline Total $\mathrm{Mg}\left(\mathrm{mg} \mathrm{kg}^{-1}\right)$ & 490 & 900 \\
\hline Total Cd $\left(\mathrm{mg} \mathrm{kg}^{-1}\right)$ & 1.04 & 2.59 \\
\hline Total $\mathrm{Cu}\left(\mathrm{mg} \mathrm{kg}^{-1}\right)$ & 8.45 & 20.72 \\
\hline Total Mn $\left(\mathrm{mg} \mathrm{kg}^{-1}\right)$ & 88.60 & 320 \\
\hline Total $\mathrm{Pb}\left(\mathrm{mg} \mathrm{kg}^{-1}\right)$ & 28.85 & 13.35 \\
\hline Total Zn $\left(\mathrm{mg} \mathrm{kg}^{-1}\right)$ & 138 & 720 \\
\hline
\end{tabular}

Effects of $\mathrm{pH}$ and sewage sludge on yield, concentration and uptake of different nutrient elements in Ipomoea aquatica

\section{Effects on the dry matter yield of Ipomoea}

The dry matter production of Ipomoea was found to decrease significantly $(\mathrm{p} \leq 0.05)$ with increasing $\mathrm{pH}$ of the soils, where as the yield was observed to increase insignificantly due to the application of sewage sludge (SS) in most cases (Table IV). Significant $(\mathrm{p} \leq 0.05) \mathrm{pH} \times \mathrm{SS}$ interaction effects were observed on the dry matter yield of Ipomoea. Treatment with sewage sludge at the lowest $\mathrm{pH}\left(\mathrm{S}_{1} \mathrm{pH}_{0}\right)$ produced the maximum yield (2.43 gm/pot), while the minimum yield (1.46 $\mathrm{gm} / \mathrm{pot})$ was observed at the highest $\mathrm{pH}\left(\mathrm{S}_{1} \mathrm{pH}_{3}\right)$. Thus, the minimum yields were obtained at the maximum $\mathrm{pH}$ level $(\mathrm{pH}=7.8)$ for both sludge amended and non-amended soils indicating that higher $\mathrm{pH}$ level is not favorable for the growth of Ipomoea aquatica.

\section{Effects on the accumulation of $\mathrm{N}, \mathrm{P}, \mathrm{K}, \mathrm{Ca}$ and $\mathrm{Mg}$ in Ipomoea}

An increase in the concentration of different plant nutrient elements, viz., N, P, K, Ca and Mg in Ipomoea aquatica was observed with increasing the $\mathrm{pH}$ of the soils in most cases (Table V). The concentration of the elements in the plants was, in general, higher for the sludge-amended soils compared to that of the non amended soils. $\mathrm{pH}$, sewage sludge and their interaction have been found to have significant $(p \leq 0.05)$ effects on the accumulation of $\mathrm{N}$ and $\mathrm{K}$ in the plants, whereas the effects were found to be insignificant for $\mathrm{P}$ and $\mathrm{Ca}$. Sewage sludge showed insignificant effect on $\mathrm{Mg}$ accumulation in Ipomoea. Higher content of the elements in the plants for the sludge-amended soils was perhaps due to the higher yield of the plants as well as the gain of surplus nutrients from the sewage sludge amended soil.

Table III: Changes in soil pH with time due to addition of $\mathrm{Ca}(\mathrm{OH})_{2}$.

\begin{tabular}{c|c|c|c|c|c}
\hline \multirow{2}{*}{ Lime level } & Amount of & \multicolumn{4}{|c}{$\mathrm{pH}$ values after different time intervals } \\
\cline { 3 - 5 } & $\mathrm{Ca}(\mathrm{OH})_{2}(\mathrm{~g} / \mathrm{pot})$ & 7 days & 14 days & 21 days & 28 days \\
\hline $\mathrm{L}_{0}$ & 0.00 & 4.70 & 4.68 & 4.71 & 4.74 \\
$\mathrm{~L}_{1}$ & 0.01 & 5.21 & 5.36 & 5.50 & 5.70 \\
$\mathrm{~L}_{2}$ & 0.02 & 6.10 & 6.23 & 6.39 & 6.60 \\
$\mathrm{~L}_{3}$ & 0.04 & 7.10 & 7.21 & 7.40 & 7.80 \\
$\mathrm{~L}_{4}$ & 0.06 & 7.62 & 7.83 & 8.00 & 8.17 \\
$\mathrm{~L}_{5}$ & 0.08 & 7.69 & 7.97 & 8.11 & 8.20 \\
$\mathrm{~L}_{6}$ & 0.10 & 8.20 & 8.42 & 8.23 & 8.50 \\
$\mathrm{~L}_{7}$ & 0.12 & 8.23 & 8.43 & 8.29 & 8.48 \\
$\mathrm{~L}_{8}$ & 0.16 & 8.27 & 8.39 & 8.42 & 8.60 \\
$\mathrm{~L}_{9}$ & 0.20 & 8.24 & 8.38 & 8.21 & 8.58 \\
$\mathrm{~L}_{10}$ & 0.24 & 11.12 & 11.20 & 11.15 & 11.35 \\
$\mathrm{~L}_{11}$ & 0.28 & 11.18 & 11.31 & 11.29 & 11.61 \\
$\mathrm{~L}_{12}$ & 0.30 & 11.23 & 11.28 & 11.37 & 11.62 \\
\hline
\end{tabular}


Table IV: Dry matter yield of Ipomoea with corresponding $\mathrm{pH}$ and sewage sludge levels.

\begin{tabular}{c|c|c}
\hline \multicolumn{2}{c|}{ Treatment } & \multirow{2}{*}{$\begin{array}{c}\text { Dry matter yield } \\
\text { (g/pot) }\end{array}$} \\
\hline \multirow{3}{*}{ Sewage sludge } & $\mathrm{pH}$ levels & 2.40 \\
$\mathrm{~S}_{0}$ & $\mathrm{pH}_{0}$ & 2.11 \\
& $\mathrm{pH}_{1}$ & 2.00 \\
& $\mathrm{pH}_{2}$ & 1.64 \\
& $\mathrm{pH}_{3}$ & 2.43 \\
$\mathrm{~S}_{1}$ & $\mathrm{pH}_{0}$ & 2.23 \\
& $\mathrm{pH}_{1}$ & 2.07 \\
& $\mathrm{pH}_{2}$ & 1.46 \\
\hline
\end{tabular}

LSD at $5 \%: \mathrm{pH}=0.33, \mathrm{SS}=\mathrm{ns}, \mathrm{pH} \times \mathrm{SS}=0.33$

\section{Effects on the uptake of $\mathrm{N}, \mathrm{P}, \mathrm{K}, \mathrm{Ca}$ and $\mathrm{Mg}$ in Ipomoea}

The uptake of the elements by Ipomoea was calculated by multiplying the concentration of the elements in the dry matter with the total dry matter produced. The results are expressed as mg per pot. Higher amounts of $\mathrm{N}, \mathrm{P}, \mathrm{K}$ and $\mathrm{Mg}$ were taken up by Ipomoea from the sewage sludge treated soils than from the non treated soils (Table VI). At the maximum $\mathrm{pH}$ level, viz. $7.8\left(\mathrm{pH}_{3}\right)$, uptake of the elements per pot was decreased to a minimum in all the soils; the reason, perhaps, being the lower yield of the crop. The uptake of $\mathrm{N}$ and $\mathrm{Mg}$ by Ipomoea varied significantly $(\mathrm{p}<0.01)$ due to the change in $\mathrm{pH}$ and the sewage sludge, whereas the effects of $\mathrm{pH}$ and sewage sludge did not show any significant variation in the uptake of $\mathrm{P}$ and $\mathrm{Ca}$. The influence of $\mathrm{pH}$ on the uptake of $K$ was found to be highly significant $(p<0.01)$, while the application of sewage sludge as well as $\mathrm{pH} \times \mathrm{SS}$ interaction showed insignificant effects on the plant uptake of $\mathrm{K}$.

\section{Effects on the accumulation of $\mathrm{Cd}, \mathrm{Cu}, \mathrm{Fe}, \mathrm{Mn}$ and $\mathrm{Zn}$ in Ipomoea}

High concentrations of the metal elements, viz., $\mathrm{Cd}, \mathrm{Cu}, \mathrm{Fe}$, $\mathrm{Mn}$ and $\mathrm{Zn}$ in Ipomoea were found for both sludge amended and non amended soils at all the $\mathrm{pH}$ levels (Table VII). Fe concentration in Ipomoea was found to be higher in the non treated soils, while elevated contents of $\mathrm{Cd}, \mathrm{Cu}, \mathrm{Mn}$ and $\mathrm{Zn}$ in the plants were observed for the sludge-treated soils, indicating the availability of these elements in soils due to the applied sewage sludge. Lesser amount of Fe in the plants grown in the sludge-treated soils might be due to the antagonistic interaction between $\mathrm{Fe}$ and the other elements, viz., $\mathrm{N}, \mathrm{P}, \mathrm{K}, \mathrm{Ca}, \mathrm{Mg}, \mathrm{Cu}, \mathrm{Mn}$ and $\mathrm{Zn}$ (Pendius 1985). Increased concentration of these metal elements in plants due to application of sewage sludge in soil has also been reported by Barbarick et al. (1998), Selivanovskaya et al. (2001) and Snyman et al. (1998). pH, sewage sludge and their interaction have been found to have highly significant $(\mathrm{p}<0.01)$ effects on the contents of $\mathrm{Zn}$ and $\mathrm{Mn}$ in Ipomoea, whereas on the concentration of $\mathrm{Cd}$ in Ipomoea the effects were not significant. Application of sewage sludge showed significant $(\mathrm{p} \leq 0.05)$ effects on the accumulation of $\mathrm{Cu}$ and $\mathrm{Fe}$ in Ipomoea.

According to Sauerbeck (1982), Kashem and Singh (1999) and Chowdhury et al. (2010), the normal level of $\mathrm{Cd}$ and $\mathrm{Zn}$ in plants varies from $0.2-2$ and $20-100 \mathrm{mg} \mathrm{kg}^{-1}$, respectively, while the toxic level of the metals range from 15-20 and

Table V: Concentration (\%) of N, P, K, Ca and Mg in Ipomoea with corresponding pH and sewage sludge treatments.

\begin{tabular}{|c|c|c|c|c|c|c|}
\hline \multicolumn{2}{|c|}{ Treatment } & \multirow[b]{2}{*}{$\mathrm{N}$} & \multirow[b]{2}{*}{$\mathrm{P}$} & \multirow[b]{2}{*}{ K } & \multirow[b]{2}{*}{$\mathrm{Ca}$} & \multirow[b]{2}{*}{$\mathrm{Mg}$} \\
\hline Sewage sludge & $\mathrm{pH}$ level & & & & & \\
\hline \multirow{6}{*}{$\mathrm{S}_{0}$} & $\mathrm{pH}_{0}$ & 1.42 & 0.73 & 0.05 & 0.14 & 0.31 \\
\hline & $\mathrm{pH}_{1}$ & 1.51 & 0.75 & 0.07 & 0.15 & 0.35 \\
\hline & $\mathrm{pH}_{2}$ & 1.55 & 0.79 & 0.07 & 0.14 & 0.34 \\
\hline & $\mathrm{pH}_{3}$ & 1.55 & 0.94 & 0.08 & 0.13 & 0.36 \\
\hline & $\mathrm{pH}_{0}$ & 1.69 & 0.72 & 0.07 & 0.12 & 0.40 \\
\hline & $\mathrm{pH}_{1}$ & 1.71 & 0.88 & 0.08 & 0.13 & 0.41 \\
\hline \multirow[t]{2}{*}{$\mathrm{S}_{1}$} & $\mathrm{pH}_{2}$ & 1.84 & 0.83 & 0.06 & 0.15 & 0.37 \\
\hline & $\mathrm{pH}_{3}$ & 1.89 & 0.66 & 0.07 & 0.16 & 0.32 \\
\hline \multirow{3}{*}{$\begin{array}{l}\text { LSD value at } \\
5 \% \text { level }\end{array}$} & $\mathrm{pH}$ & 0.12 & ns & 0.02 & ns & 0.04 \\
\hline & SS & 0.22 & $\mathrm{~ns}$ & 0.03 & ns & ns \\
\hline & $\mathrm{pH} \times \mathrm{SS}$ & 0.12 & ns & 0.02 & $\mathrm{~ns}$ & 0.04 \\
\hline
\end{tabular}

ns = not significant, $\mathrm{SS}=$ sewage sludge 
Table VI: Uptake (mg/pot) of N, P, K, Ca and Mg in Ipomoea with corresponding pH and sewage sludge treatments.

\begin{tabular}{|c|c|c|c|c|c|c|}
\hline \multicolumn{2}{|c|}{ Treatment } & \multirow[b]{2}{*}{$\mathrm{N}$} & \multirow[b]{2}{*}{$\mathrm{P}$} & \multirow[b]{2}{*}{$\mathrm{K}$} & \multirow[b]{2}{*}{$\mathrm{Ca}$} & \multirow[b]{2}{*}{$\mathrm{Mg}$} \\
\hline Sewage sludge & $\mathrm{pH}$ level & & & & & \\
\hline \multirow{6}{*}{$\mathrm{S}_{0}$} & $\mathrm{pH}_{0}$ & 34.1 & 17.5 & 1.22 & 3.36 & 7.44 \\
\hline & $\mathrm{pH}_{1}$ & 31.9 & 15.6 & 1.49 & 3.17 & 7.39 \\
\hline & $\mathrm{pH}_{2}$ & 31.0 & 15.9 & 1.36 & 2.80 & 6.80 \\
\hline & $\mathrm{pH}_{3}$ & 25.4 & 15.3 & 1.26 & 2.13 & 5.90 \\
\hline & $\mathrm{pH}_{0}$ & 41.1 & 17.5 & 1.82 & 2.92 & 9.72 \\
\hline & $\mathrm{pH}_{1}$ & 54.2 & 19.7 & 1.69 & 2.99 & 9.14 \\
\hline \multirow{5}{*}{$\begin{array}{l}\text { LSD value at } 5 \% \\
\text { level }\end{array}$} & $\mathrm{pH}_{2}$ & 38.1 & 17.2 & 1.34 & 3.11 & 7.66 \\
\hline & $\mathrm{pH}_{3}$ & 27.6 & 9.70 & 1.01 & 2.34 & 4.68 \\
\hline & $\mathrm{pH}$ & 2.26 & ns & 0.08 & ns & 0.11 \\
\hline & $\mathrm{SS}$ & 3.92 & ns & ns & ns & 0.17 \\
\hline & $\mathrm{pH} \times \mathrm{SS}$ & 2.26 & ns & ns & ns & 0.11 \\
\hline
\end{tabular}

ns = not significant, $\mathrm{SS}=$ sewage sludge

150-200 $\mathrm{mg} \mathrm{kg}^{-1}$, respectively. Zinc is one of the micronutrients essential for normal plant growth, but only a small amount of $\mathrm{Zn}$ is required (Adriano 1986). Although the concentration of $\mathrm{Cd}$ in the plants grown on the soils, both nonamended and amended with sewage sludge, exceeded the normal range, it has been found to be in the tolerable range, while $\mathrm{Zn}$ concentration in Ipomoea was observed to exceed even the toxic level for both types of the soil (Table VII).

Although $\mathrm{Cu}$ is essential for plant growth, a very small amount of $\mathrm{Cu}$ is required by plants (Adriano 1986). The normal level of $\mathrm{Cu}$ in plants varies from $3-10 \mathrm{mg} \mathrm{kg}^{-1}$, while the toxic level of the metal ranges from $10-20 \mathrm{mg} \mathrm{kg} \mathrm{kg}^{-1}$ (Sauerbeck 1982; Kashem and Singh 1999; Chowdhury et al. 2010). In the present study, elevated levels of $\mathrm{Cu}$ toxicity were found for the plants under both of the soils (Table VII). $\mathrm{Fe}$ and $\mathrm{Mn}$ are required by plants in only small quantities, large amounts being toxic (Tisdale et al. 1993). The typical contents of $\mathrm{Fe}$ and $\mathrm{Mn}$ in plants are 100 and $50 \mathrm{mg} \mathrm{kg}^{-1}$, respectively (Imamul Huq and Alam 2005). The concentrations of $\mathrm{Fe}$ and $\mathrm{Mn}$ in Ipomoea under both the sewage sludge amended and non-amended soils showed higher accumulation of the elements (Table VII).

Effects on the uptake of $\mathrm{Cd}, \mathrm{Cu}, \mathrm{Fe}, \mathrm{Mn}$ and $\mathrm{Zn}$ in Ipomoea

The uptake of the metal elements by Ipomoea was calculated by multiplying the concentration of the elements in the

Table VII: Concentration of $\mathrm{Cd}, \mathrm{Cu}, \mathrm{Fe}, \mathrm{Mn}$ and $\mathrm{Zn}$ in Ipomoea with corresponding pH and sewage sludge treatments.

\begin{tabular}{|c|c|c|c|c|c|c|}
\hline \multicolumn{2}{|c|}{ Treatment } & \multirow{2}{*}{$\begin{array}{c}\mathrm{Cd} \\
\left(\mathrm{mg} \mathrm{kg}^{-1}\right)\end{array}$} & \multirow{2}{*}{$\begin{array}{c}\mathrm{Cu} \\
\left(\mathrm{mg} \mathrm{kg}^{-1}\right)\end{array}$} & \multirow{2}{*}{$\begin{array}{l}\mathrm{Fe} \\
(\%)\end{array}$} & \multirow{2}{*}{$\begin{array}{c}\mathrm{Mn} \\
\left(\mathrm{mg} \mathrm{kg}^{-1}\right)\end{array}$} & \multirow{2}{*}{$\begin{array}{c}\mathrm{Zn} \\
\left(\mathrm{mg} \mathrm{kg}^{-1}\right)\end{array}$} \\
\hline Sewage sludge & $\mathrm{pH}$ level & & & & & \\
\hline \multirow{6}{*}{$\mathrm{S}_{0}$} & $\mathrm{pH}_{0}$ & 11.24 & 47.87 & 0.095 & 86.50 & 209.58 \\
\hline & $\mathrm{pH}_{1}$ & 11.05 & 45.88 & 0.084 & 92.50 & 244.76 \\
\hline & $\mathrm{pH}_{2}$ & 11.26 & 42.63 & 0.081 & 158.75 & 291.03 \\
\hline & $\mathrm{pH}_{3}$ & 10.95 & 37.00 & 0.088 & 86.25 & 251.70 \\
\hline & $\mathrm{pH}_{0}$ & 11.86 & 57.50 & 0.077 & 122.50 & 292.70 \\
\hline & $\mathrm{pH}_{1}$ & 12.18 & 45.88 & 0.063 & 183.75 & 277.03 \\
\hline \multirow[t]{2}{*}{$\mathrm{S}_{1}$} & $\mathrm{pH}_{2}$ & 11.28 & 51.38 & 0.067 & 192.50 & 298.64 \\
\hline & $\mathrm{pH}_{3}$ & 12.83 & 46.00 & 0.065 & 167.50 & 157.63 \\
\hline \multirow{3}{*}{$\begin{array}{l}\text { LSD value } \\
\text { at } 5 \% \text { level }\end{array}$} & $\mathrm{pH}$ & ns & ns & ns & 15.68 & 21.26 \\
\hline & SS & $\mathrm{ns}$ & 13.38 & 0.07 & 12.83 & 36.82 \\
\hline & $\mathrm{pH} \times \mathrm{SS}$ & ns & $\mathrm{ns}$ & ns & 15.68 & 21.26 \\
\hline
\end{tabular}

ns $=$ not significant, $\mathrm{SS}=$ sewage sludge 
dry matter with the total dry matter produced. The results are expressed as mg per pot. Uptake of Cd by Ipomoea varied from 0.018 to $0.029 \mathrm{mg} /$ pot being slightly higher in the sludge-treated soils, whereas the lowest uptake $(0.018$ $\mathrm{mg} / \mathrm{pot})$ was found for the level of $\mathrm{pH}_{3}(7.8)$ in both type of soils (Table VIII). Copper was taken up by the plants in relatively higher amounts in treated $(0.139 \mathrm{mg} / \mathrm{pot})$ compared to untreated $(0.115 \mathrm{mg} / \mathrm{pot})$ at the $\mathrm{pH}$ level of $4.7\left(\mathrm{pH}_{0}\right)$. At all the $\mathrm{pH}$ levels, higher amount of Fe was taken up by the plants from the non-sludge treated soils. Manganese and $\mathrm{Zn}$ uptake was found to be higher for the sludge-treated soils. This may be due to the fact that these metals were in a more labile state in the sludge-treated soils than in the non treated soils. $\mathrm{pH}$ has been found to have highly significant $(\mathrm{p}<0.01)$ effect on the uptake of $\mathrm{Cd}, \mathrm{Cu}, \mathrm{Mn}$ and $\mathrm{Zn}$ by Ipomoea . Application of sewage sludge in the soils showed highly significant $(\mathrm{p} \leq 0.05)$ effect on the plant uptake of $\mathrm{Mn}$ and $\mathrm{Zn}$.
Table IX: Changes in soil pH after harvest of Ipomoea.

\begin{tabular}{c|c|c}
\hline \multirow{2}{*}{$\begin{array}{c}\text { Initial } \\
\text { soil } \mathrm{pH}\end{array}$} & \multicolumn{2}{|c}{ After harvest soil $\mathrm{pH}$} \\
\cline { 2 - 3 } & Non-amended soil & Sewage sludge amended soil \\
\hline 4.7 & 5.67 & 5.68 \\
5.7 & 6.10 & 6.20 \\
6.6 & 6.39 & 6.48 \\
7.8 & 7.20 & 7.10 \\
\hline
\end{tabular}

\section{Conclusion}

The results of the present study substantiate that liming can bring a change in the response of plants to nutrients as well as to toxic heavy metals available in soil due to application of sewage sludge. The concentration of the nutrient and metal elements in the plant tissues and the uptake of the elements into the plants indicate the bioavailability of the elements in soil as a result of addition of sewage sludge. The

Table VIII: Uptake (mg/pot) of $\mathrm{Cd}, \mathrm{Cu}, \mathrm{Fe}, \mathrm{Mn}$ and $\mathrm{Zn}$ in Ipomoea with corresponding pH and sewage sludge treatments.

\begin{tabular}{|c|c|c|c|c|c|c|}
\hline \multicolumn{2}{|c|}{ Treatment } & \multirow[b]{2}{*}{$\mathrm{Cd}$} & \multirow[b]{2}{*}{$\mathrm{Cu}$} & \multirow[b]{2}{*}{$\mathrm{Fe}$} & \multirow[b]{2}{*}{$\mathrm{Mn}$} & \multirow[b]{2}{*}{$\mathrm{Zn}$} \\
\hline Sewage sludge & $\mathrm{pH}$ level & & & & & \\
\hline \multirow{6}{*}{$\mathrm{S}_{0}$} & $\mathrm{pH}_{0}$ & 0.027 & 0.115 & 2.27 & 0.208 & 0.503 \\
\hline & $\mathrm{pH}_{1}$ & 0.023 & 0.097 & 1.76 & 0.195 & 0.516 \\
\hline & $\mathrm{pH}_{2}$ & 0.022 & 0.085 & 1.62 & 0.318 & 0.582 \\
\hline & $\mathrm{pH}_{3}$ & 0.018 & 0.061 & 1.44 & 0.142 & 0.259 \\
\hline & $\mathrm{pH}_{0}$ & 0.029 & 0.139 & 1.87 & 0.298 & 0.711 \\
\hline & $\mathrm{pH}_{1}$ & 0.027 & 0.102 & 1.41 & 0.409 & 0.617 \\
\hline \multirow[t]{2}{*}{$\mathrm{S}_{1}$} & $\mathrm{pH}_{2}$ & 0.023 & 0.106 & 1.39 & 0.398 & 0.618 \\
\hline & $\mathrm{pH}_{3}$ & 0.018 & 0.067 & 0.95 & 0.245 & 0.230 \\
\hline \multirow{3}{*}{$\begin{array}{l}\text { LSD value at } 5 \% \\
\text { level }\end{array}$} & $\mathrm{pH}$ & 0.05 & 0.02 & NS & 0.08 & 0.21 \\
\hline & SS & ns & ns & ns & 0.15 & 0.03 \\
\hline & $\mathrm{pH} \times \mathrm{SS}$ & ns & ns & ns & ns & 0.21 \\
\hline
\end{tabular}

ns = not significant, $\mathrm{SS}=$ sewage sludge

\section{Changes in soil pH after harvest of Ipomoea}

A small change in all the initial $\mathrm{pH}$ of both of the soils has been observed after harvest of Ipomoea grown in the pots (Table IX). The levels of $\mathrm{pH}_{0}$ (4.7) and $\mathrm{pH}_{1}$ (5.7) were found to increase to 5.67 and 6.1, respectively, in the non amended soils and to 5.68 and 6.20 , respectively, for the soils treated with sewage sludge. The other two levels of $\mathrm{pH}_{2}$ (6.6) and $\mathrm{pH}_{3}$ (7.8) were observed to reduce from their initial values in both types of the soils. However, the changes in the $\mathrm{pH}$ of the sludge amended soils and non amended soils were found to be insignificant. study suggests that acid soils may be used for agricultural purpose through amendment with more levels of sewage sludge. However, further research with more crops is needed to make any recommendation on the commercial use of sewage sludge.

\section{References}

Adriano D. C. (1986). Trace Elements in the Terrestrial Environment. Springer-Verlag Inc., New York. P. 1-45.

Aggelides S. M. and Londra P. A. (2000). Effect of compost produced from town wastes and sewage sludge on the 
physical properties of a loamy and a clay soil. Bioresource Tech. 71: 253-259.

Barbarick K. A. Ippolito J. A. and Westfall D. G. (1998). Extractable trace elements in soil profile after years of biosolids application. J. Environ. Qual. 27: 801-805.

Basta N. T. and Sloan J. J. (1999). Bioavailability of heavy metals in strongly acidic soils treated with exceptional quality biosolids. J. Environ. Qual. 28: 633-638.

Benitez E. Romero M. Gomez M. and Nogales F.R. (2001) Biosolid and biosolid ash as source of heavy metals. Water, Air and Soil Pollut. 132: 75-80.

Brady N. C. and Weil R. R. (2002). The Nature and Properties of Soils. Pearson Education. 13th ed. 387391.

Chowdhury M. T. A. Nesa L. Kashem M. A. and Imamul Huq, S.M. (2010). Assessment of the phytoavailability of $\mathrm{Cd}, \mathrm{Pb}$ and $\mathrm{Zn}$ using various extraction procedures. Pedologist. 53(3): 80-95.

Fang M. and Wong J. W. C. (1999). Effects of lime amendment on availability of heavy metals and maturation in sewage sludge composition. Environ. Pollut. 106: 83-89.

Imamul Huq S. M. and Alam M. D. (2005). A Handbook on Analyses of Soil, Plant, and Water. BACER-DU, University of Dhaka, Bangladesh. P. xxii-246.

Kashem M. A. and Singh B. R. (1999). Heavy metal contamination of soil and vegetation in the vicinity of industries in Bangladesh. Water Air Soil Pollut. 115: 347-361.

Keller C. McGrath S. P. and Dunham S. J. (2002). Trace metal leaching through a soil grassland system after sewage sludge application. J. Environ. Qual. 31: 15501560.

Krebs R. Gupta S. K. Furrer G. and Schulin R. (1998). Solubility and plant uptake of metals with and without liming of sludge amended soils. J. Environ. Qual. 27: $18-23$.

Lagerwerff J. V. Biersdorf G. T. Milberg R. P. and Brower D. L. (1977). Effects of incubation and liming on yield and heavy metal uptake by rye from sewage sludged soil. J. Environ. Qual. 6(4): 427-430.
Little D. A. Reneau R. B. and Martens D. C. (1991). Lime stabilized and chemically fixed sewage sludge as lime amendments. Bioresource Tech. 37: 93-102.

Peles J. D. Brewer S. R. and Barret G. W. (1998). Heavy metal accumulation by old field plant species during recovery of sludge treated ecosystems. Am. Mild. Nat. 140: $245-251$.

Pendias A. K. (1985). Trace Elements in Soils and Plants. CRC Press, Inc. Boca Raton, Florida. P. 67.

Sauerbeck D. (1982). Welche Schwermetallgehalte in Pflanzen durfen nicht berschriten werden, um Wachstum sbeentrachtigungenzu vermeident Landw. Forsch. Sonderheft Kongressband): 108-129.

Selivanovskaya S. Y. Latypova V. Z. Kiyamova S. N. and Alimova F. K. (2001). Use of microbial parameters to access treatment methods of municipal sewage sludge applied to gray forest soils of Tatarstan. Agric. Ecosys. and Environ. 86: 145-153.

Sikder T. Joardar J. C. and Imamul Huq S. M. (2007). Sewage sludge as soil ameliorator. Bangladesh $J$. Agric. and Environ. 3(1): 63-73.

Snyman H. G. de Jong J. M. and Aveling, A. S. (1998). The stabilization of sewage sludge applied to agricultural land and the effects on maize seedlings. Water Sci. Tech. 38: 87-95.

Tisdale S. L. Nelson W. L. Beaton J. D. and Havlin J. L. (1993). Soil Fertility and Fertilizers. 5th ed. Pearson Education, New Jersey, USA. pp. 90-93.

USDA (United States Department of Agriculture) (1951). Soil Survey Manual by Soil Survey Staff. Bureau of Plant Industry. Soil and Agric. Engr. 80: 503.

White C. S. Loftin S. R. and Agular R. (1997). Application of biosolid to degraded semi-arid rangeland: Nine-year responses. J. Environ. Qual. 26: 1663-1671.

Yingming L. and Corey R. B. (1993). Redistribution of sludge borne $\mathrm{Cd}, \mathrm{Cu}$ and $\mathrm{Zn}$ in a cultivated plot. $J$. Environ. Qual. 22: 1-8.

Received : June 27, 2010;*

Accepted : July 28, 2011 